\title{
Factors Influencing the Social Responsibility of a Public Hospital
}

\author{
Alejandra López-Salazar ${ }^{1}$, José Felipe Ojeda-Hidalgo ${ }^{2} \&$ Martha Ríos-Manríquez $^{1}$ \\ ${ }^{1}$ Departamento de Finanzas y Administración, Universidad de Guanajuato, Campus Celaya-Salvatierra, Guanajuato, \\ México \\ ${ }^{2}$ Universidad Politécnica de Guanajuato, Guanajuato, México \\ Correspondence: Alejandra López-Salazar, Departamento de Finanzas y Administración, Universidad de Guanajuato, \\ Campus Celaya-Salvatierra, Guanajuato, México. Tel: 52-461-140-9385.
}

Received: October 4, 2016

Accepted: October 20, 2016

Online Published: November 12, 2016

doi:10.5430/ijba.v7n6p42

URL: http://dx.doi.org/10.5430/ijba.v7n6p42

\begin{abstract}
Corporate Social Responsibility (CSR) has been little studied in the health sector. The objective of this research is to identify the factors affecting CSR from the perception of 256 workers, based on the guidelines of ISO 26000 in a public hospital. The results show that good governance, respect for consumer affairs, active participation and community development positively and significantly influence the perception by employees of the level of social responsibility of the organization. Respect for human rights, labor practices, environmental protection and fair operating practices are not significant in explaining the level of CSR.
\end{abstract}

Keywords: corporate social responsibility, hospitals

\section{Introduction}

Social responsibility has been approached from different perspectives since the first great civilizations until recent times, including: ethics (Zaratustra, 1767 a.C; Hammurabi, 1728 BCE; Platón, 387 BCE.; Aristóteles, 350 BCE Sacconi, 2004; Jensen, 2009; Cersósimo, 2002), the social balance (Platón, 387 BCE.; Aristóteles, 350 BCE.; Jaulín, 2013), economics (Hobbes, 1651; Locke, 1689; Smith, 1776), the common good (Cicerón, 51 BCE.; San Agustín, 426; Murphy, 2005; Crosby y Bryson, 2005; Deneulin, 2006), altruism (Comte, 1851; Mills, 1863; Dawkins, 1976) and philanthropy (Cicerón, 51 BCE; San Agustín, 426; Murphy, 2005; Crosby y Bryson, 2005; Deneulin, 2006). Philanthropy establishes corporate contributions (Ojeda and Lira, 2014), and raises questions about the true social role of businessmen. These questions were developed from the positions of Clark (1916), Sheldon (1924), Barnard (1938), Kreps (1940) and Simon (1945) and are based on the work of Bowen (1953) who coined the term corporate social responsibility. The 1980's sets a turning point because it begins to link social responsibility with other topics that are complementary (Jones, 1980; Wartick and Cochran, 1985; Moser, 1986; Epstein, 1987 and Frederick, 1987) and in this decade the theory of interested parties or stakeholders (Freeman, 1984) which emphasizes the importance of society in understanding the phenomenon of social responsibility arises, besides giving the holistic nature that remains to date.

Several studies have developed CSR in different sectors (López, Ojeda, and Ríos, 2016; López, Contreras and Molina, 2011). However, research on health institutions is very limited, especially in Mexico; and on the other hand, the results found in the few developed studies in other countries has very different results. In this regard, the development of research focused on evaluating the behavior responsible for hospitals is of great importance. First, because they are in charge of the health service of the whole society; second, because there are many negative implications when a philosophy of CSR is not incorporated into the functions, activities and decisions of a health institution. Third, because it is imperative that worker's health institutions are conducted based on a code of ethics, that of certainty to users of the reliability and safety of service granted. Therefore, this study aims to analyze the factors that influence the behavior of a company responsible health sector, depending on the perception of workers.

\section{Literature Review}

\subsection{Stakeholder Theory}

Freeman (1984) defined stakeholders as any group or individual who can or is affected by the achievement of the objectives of an organization or a person or group of people who contribute voluntarily or involuntarily in the 
activities and capacities of generating wealth, and therefore are potential beneficiaries, or, on the other hand, can also be those who take risks (Post, Preston and Sachs, 2002). According to Werther and Chandler (2011), stakeholders are groups or individuals who are interested in the activities of the company (Table 1).

Granillo and Ojeda (2012) and De la Garza and Gúzman (2013) outlined a proposal for the development of stakeholder theory, starting with Freeman (1984) who claimed that managers must adapt their policies to meet numerous consists before not only shareholders. These stakeholders include employees, customers, suppliers and community organizations.

Table 1. Types of stakeholders and legitimate interests

\begin{tabular}{|c|c|}
\hline Types & Legitimate interest \\
\hline $\begin{array}{l}\text { Partners, shareholders, } \\
\text { and investors }\end{array}$ & Profit, Profitability, investments and management \\
\hline Managers & Management capacity, prestige, income \\
\hline Employees & $\begin{array}{l}\text { Wages, social benefits, health, safety, stability, promotion, employability, } \\
\text { participation, training, development, non-discrimination, labor climate }\end{array}$ \\
\hline Opinion leaders & Transparency and information accurate and updated \\
\hline Customers & $\begin{array}{l}\text { Fair relationship quality-price, truthful information, warranties, health, safety, and } \\
\text { after-sales }\end{array}$ \\
\hline Financial institutions & Transparency, solvency, fight against corruption \\
\hline Competitors & Respect for rules of free competition, reciprocity and fulfillment of commitments \\
\hline $\begin{array}{l}\text { Suppliers and } \\
\text { subcontractors }\end{array}$ & $\begin{array}{l}\text { Respect for free market rules, ability to pay, clear information, business opportunities, } \\
\text { respect for trademarks and industrial property }\end{array}$ \\
\hline $\begin{array}{l}\text { Local communities, } \\
\text { countries, and societies }\end{array}$ & $\begin{array}{l}\text { Compliance, contribution to development, cooperation with scientific institutions, } \\
\text { cultural, universities, environment, and non-governmental organizations }\end{array}$ \\
\hline Public administration & $\begin{array}{l}\text { Legality, contribution to development, collaboration with scientific, cultural } \\
\text { institutions, universities, environment, and non-governmental organizations }\end{array}$ \\
\hline Political parties & Legality and contribution to development \\
\hline Churches & Respect for their beliefs and moral values and citizen participation \\
\hline Unions & Respect for and promotion of labor rights \\
\hline Universities & Research, development, and training \\
\hline
\end{tabular}

Source: Navarro (2012) cited by Hernandez and Hernandez (2014).

Donaldson and Preston (1995) emphasize the moral and ethical dimensions of the theory of interested parties and business opportunities involved in social responsibility. For Jones (1995) companies involved in activities with stakeholders based on trust and cooperation have an incentive, to be honest, and ethical, and that such behavior is beneficial to the organization. Under the concept of the Triple Bottom Line, it requires that the social responsibility of a company is to stakeholders rather than shareholders. In this case, when speaking of stakeholders, it refers to anyone who is influenced, either directly or indirectly, by the actions of the company. According to the theory of stakeholders, the company should be used as a vehicle for coordinating stakeholder interests, rather than maximizing shareholders' interests (Elkington, 1998).

Clarkson (1995) proposes that we classify stakeholders as primary or secondary, depending on the contribution of each group to the survival of the organization so that primary stakeholders are those that contribute to the survival and the seconds are those affecting, or they are affected by the organization. Therefore it becomes important to the ability of the organization to achieve its economic and social objectives, ensuring that the primary group of stakeholders continues to be part of the system and the value chain of the organization, by meeting the legitimate interests of each type of stakeholders. 
The concept of stakeholders has suffered, like the concept of social responsibility, a constant from the studies and immersions that have made progress. For Jones (1980), companies have an obligation to build groups in society that are not just shareholders, and go beyond the provisions of the law or union contract, indicating that there is a reason that goes beyond the property.

Freeman (1984) offers a broader scope of the meaning of stakeholders based on the logic of the power dependence concept and states that any group or individual who can affect or is affected by the achievement of the objectives of the organization. More recently, Freeman, Harrison, Wicks, Parmar and De Colle (2010) suggested that company that is responsible towards its stakeholders is one that looks fully to both society and businesses, which is not manifested equally in all organizations, but a pragmatic approach promoted under the management of relations with all its stakeholders as a primary activity for success.

The stakeholder theory has been approached from different approaches, such as power dependence (Table 2). This approach refers in particular to the stakeholder theory and how advocates the redistribution of benefits to stakeholders (both stakeholders and Shareholders) and the redistribution of power in making important decisions for stakeholders (Freeman, 2002). Post, Preston and Sachs (2002) state that companies must operate in the center of a network of interrelated stakeholders that create, sustain and enhance the ability to create value.

Table 2. Approach to dependency

\begin{tabular}{ll}
\hline Focus & \multicolumn{1}{c}{ Concept } \\
\hline \multirow{2}{*}{ Tey } & Those groups without whose support the organization would not exist (Freeman and Reed, \\
The interest group has power over the company, and this can affect or be affected by the \\
negotiation (Freeman and Gilbreth, 1987).
\end{tabular}

Source: Based on information from the authors.

Another approach to addressing the stakeholder theory has to do with relational approaches between stakeholders or existing in the organization (Table 3). Relationship-based approaches have been addressed more precisely through a position on the legitimacy of this relationship. For Alkhafaji (1989), this legitimacy occurs when the company is responsible for the group in question, i.e. when the stakeholder has rights over the company. In other words, it is when the socio-political communities are the main source of guidance concerning the obligations of the parties of organizations established or operating within its borders (Donaldson and Dunfee, 1994). 
Table 3. Relational approaches

\begin{tabular}{|c|c|}
\hline Focus & Concept \\
\hline \multirow{4}{*}{ Existing } & Stakeholders in relation to the organization (Thompson, Wartick, and Smith, 1991). \\
\hline & $\begin{array}{l}\text { Having some legitimate relationship, not trivial with an organization, for example, foreign } \\
\text { exchange operations, the impact of the action and responsibilities (Brenner, 1993). }\end{array}$ \\
\hline & The stakeholder's participants in the human process of creating joint value (Freeman, 1994). \\
\hline & $\begin{array}{l}\text { Stakeholders interact with the company, give value and definition (Wicks, Gilbreth, and } \\
\text { Freeman, 1994). }\end{array}$ \\
\hline \multirow{2}{*}{$\begin{array}{l}\text { Among } \\
\text { stakeholders }\end{array}$} & $\begin{array}{l}\text { The decision based on the influence of stakeholders towards the participation of the } \\
\text { stakeholders (Dill, 1975). }\end{array}$ \\
\hline & $\begin{array}{l}\text { The initial emphasis moves towards a focus on a stakeholder approach and the relationships } \\
\text { between them (Androif and Waddock, 2002). }\end{array}$ \\
\hline
\end{tabular}

Source: Based on information from the authors.

On the other hand, the legitimacy of the relationship can be confirmed by the relationship of the stakeholders with the claim, i.e., it is generated when the interest groups have a claim on the company, benefiting or being damaged by the decisions of the company, and whose benefits are respected or violated due to corporate actions (Evan and Freeman, 1988).

Specifically, this claim can be by the owners, who would be those who have a claim, property, right or interest in a corporation and its activities (Clarkson, 1995), or may also be legitimated from stakeholders, volunteers who carry some risk as a result of capital invested in a certain way, human, financial or carrying something of value in a company, just as happens with involuntary stakeholders that are placed at risk as a result of the activity of a company (Clarkson, 1994). It analyzed the position given from the contractual relationship of the organization with its stakeholders (Table 4).

Table 4. Legitimacy of the relationship from the contractual relationship

\begin{tabular}{cl}
\hline Focus & \multicolumn{1}{c}{ Concept } \\
\hline & $\begin{array}{l}\text { Those applicants who have contracts with the organization (Cornell and Shapiro, 1987). } \\
\text { Are holders of contracts (Freeman and Evan, 1990). }\end{array}$ \\
$\begin{array}{l}\text { Contractual } \\
\text { relationship }\end{array}$ & $\begin{array}{l}\text { Those participants who have a legitimate demand of enterprises established through the } \\
\text { existence of a relationship of exchange that provides the organization with critical resources } \\
\text { (contributions) and instead everyone expects that its interests are met (by incitements) (Hill } \\
\text { and Jones, 1992) }\end{array}$
\end{tabular}

Source: Based on information from the authors.

In addition to the relationship between stakeholders, other authors have analyzed from the very position of the stakeholders (Table 5). Several authors have provided some other theories to understand this position of stakeholders regarding organizations. Ansoff (1965) emphasizes the objectives of the organization and how these should be derived from the balance between the conflicting claims of various stakeholders in the company, managers, employees, shareholders, alternates, and sellers. Brenner and Cochran (1991) used the descriptive theory to argue that the nature of the stakeholders in an organization are founded on their values and their influence on decision making and nature to predict organizational behavior.

Jones (1995) assumes an instrumental stance to say that companies have a competitive advantage if the contract made with its stakeholders is based on mutual trust and cooperation. Jones and Wicks (1999) through the convergence theory shows that administrators can create moral discourse approaches for companies to focus on business. 
Another view of the concepts on stakeholders reviewed the relationship between the applicants and stakeholders with claims and influential stakeholders, who have an interest in the actions of an organization and have the ability to influence it (Savage, Nix, Whitehead \& Blair, 1991). Brenner (1995) states that stakeholders can impact or be impacted in some way by some organization.

Within the relational approach, there is a line confronting the plaintiff participants against influential participants, who have an interest in the actions of an organization and have the ability to influence it (Savage, Nix, Whitehead \& Blair, 1991). From a moral stance, it is possible to understand the division of the concept of stakeholders from the definitions of 'applicant' and the dimensions of the concept of 'influential' to clarify the moral obligations of the organization (Kaler, 2002).

Table 5. Position of stakeholders

\begin{tabular}{ll}
\hline \multicolumn{1}{c}{ Position } & \\
\hline Analysis & $\begin{array}{l}\text { The analysis of interest groups asked the manager to consider all parties that will be } \\
\text { affected or to be affected by a major decision. Asks the manager to list as many } \\
\text { stakeholders as possible, have a motive or influence the policy under consideration } \\
\text { (Mitroff, Emshoff, and Kilmann, 1979). }\end{array}$ \\
Interests & $\begin{array}{l}\text { An individual or interest group who claim to have one or more types of interests in a right } \\
\text { (legal or moral) legal title to the property or the property of the company (Carroll, 1993). }\end{array}$ \\
ID & $\begin{array}{l}\text { Identify internal stakeholders, analyzes from the connection between them and their } \\
\text { relationship with external (Greasley, 1999). }\end{array}$ \\
Dialogue & $\begin{array}{l}\text { The essence of stakeholder dialogue is the co - creation of knowledge shared by the } \\
\text { company and stakeholders (Johnson - Cramer, Berman, and Post, 2003). }\end{array}$ \\
Capitalist & $\begin{array}{l}\text { The stakeholder capitalism is based on freedom, rights, and creation by consent of } \\
\text { positive obligations. The principles of cooperation of the stakeholders, responsibility, } \\
\text { complexity, continuous creation, emerging competition, is included in this approach } \\
\text { (Freeman, Harrison, Wicks, Parmar and De Colle, 2010). }\end{array}$ \\
\hline
\end{tabular}

Source: Based on information from the authors.

Finally, the position of the stakeholders has been approached from a regulatory approach, Phillips (2003) proposes a theory of organizational management and ethics because ethics and questions of value are at the core of management oriented by stakeholders. Stakeholder theory places the concern for ethics at the heart of capitalism (Vesser, Matten, Pohl, Tolhurst \& Böhmer, 2007). Rules can be instrumental when the theory of stakeholder management is used to study corporate performance (Berman, Wicks, Kotha and Jones, 1999). It can be analyzed from the logic of fairness when competing against claims of stakeholders when identifying stakeholders is sought or when fair play is required (Phillips, 1997). From the theological perspective, the stakeholder theory adds the specification that the company's goal is to maximize the company's long-term total value (Jensen, 2002) and the position of liberalism proposes that individuals with rights and reasons may voluntarily participate in the agreements (Freeman \& Phillips, 2002).

\subsection{Social Responsibility in Health Institutions}

Hospitals are essentially socially responsible organizations, hence the interest in social responsibility is conceptualized differently from other organizations. The hospital setting and the emotional connotations of medical treatment necessitate that the concept of social responsibility conducive to the improvement in the basic service offered to citizens (health care, scientific research, and teaching) above the socially responsible initiatives common in other sectors and in other activities (Medina, 2012).

Evans and Stoddart (1990) argue that the health sector and organizations whose mission is to provide health services should participate in social activities and take an active part in social responsibility actions. However, Perez and Morales (2011) note that social responsibility in health systems is virtually zero, so it has become an urgent need for health systems and health care carried out actions relating to social liability (Abreu, David Crowther, Date \& Exports, 2005). 
Due to the need to specify social responsibility in health organizations, some specific conceptualizations of the response to social stability in this sector have been published. For Ortiz \& Palavecino (2005), socially responsible organizations are those that adopt an ethical position that has a free and active commitment to contribute to the betterment of society, tending to encourage solidarity and sustainability and to a cleaner environment.

Social responsibility has also been defined as 'the behavior of a company towards its stakeholders and society as a whole, which forces it to fulfill certain commitments' (Marin, 2008: 9, own translation). Similarly, it is possible to understand it as a complementary activity to be undertaken by companies for the improvement of the quality of life in the social, economic, and environmental dimension in order to improve their competitiveness and value-added indices (Harwood, 2008). Panwar, Han, \& Hanse (2010) understand social responsibility in health institutions and the involvement and participation of the organization in actions that will ultimately help improve the social situation.

Since the beginning of this century ethics has been actively developed, both in private business and in other organizational contexts (Hall, 2000; Ozar, Wheraney \& Emanueli, 2000; Spencer, Mills, Rorty \& Wherane, 2000), which shows a return to humanism in organizational activity.

Gonzalez (2004) argues that health organizations have to take responsibility meet the demands or legitimate interests not only of its shareholders but also their stakeholders: 'This theory is relevant because from it can be addressed not only good sanitary practices in the professional field but also in the organizational field, helping to understand and explain the possible conflicts of values, loyalties, commitments and interests' (Garcia, 2005: 79, own translation).

Arrieta \& De la Cruz (2005) state that to implement social responsibility in a health institution, we must make ethical, transparent practices, set benchmarks, clear and verifiable, require verification of data by independent agents, delimit the type of information that should be provided as institutions, to ensure the reliability of the assessment procedure and make audits.

These possible social responsibility policies should represent a '[...] set of social and corporate values (based on supporting solidarity and community) that the individual may want to incorporate into the mental model when analyzing their perception of the organization and its estimated value' (Simon and Martinez, 2002: 5, own translation). The tactics used to express and demonstrate social responsibility could include mission statements and values, speeches and advertising, i.e., contribution to education, health, care and the arts (Cutilp, Center, \& Broom, 2001).

Some recent studies suggest measuring social responsibility in health institutions from the perception of various stakeholders. Ramos (2013) uses the environmental, social, economic, stakeholders and the voluntary proposals by Dahlsrud (2008) to measure social responsibility in nine health systems in Colombia. The results showed that most institutions: a) have a commitment to users by providing quality care and to recognize and secure their rights; b) provide welfare work and respect for labor law; and, c) respect the environment through integrated waste management and environmental training.

Morales, Galeano, and Muñoz (2014) analyze the social responsibility of eleven health promotion entities from stakeholders: community, suppliers, customers, investors, and employees. In this research, the authors propose multivariate profiles determined through analysis and conclude that not make a trend either because they constitute independent trends that cater to particular dynamics.

Keyvanara and Sadat (2015) studied 21 hospitals in the city of Isfahan, Iran (of a total of 27, 11 academic, 8 private, 2 social protection, 3 armed forces, and 3 affiliated to charity) with a single stratified sample of 946 participants. The dimensions analyzed were leadership and processes, marketing, workplace, environment, and community. They found a positive relationship between the level of CSR and the type of hospital (either public or private); and they found that management commitment to CSR actions, responsible marketing and the establishment of rules, regulations and codes of ethics are the most important dimensions for health institutions.

Social responsibility may be expressed differently in different organizations. However, it is considered that the dimensions expressed are generally those expressed by the ISO 26000 (2010) governance, human rights, environment, practices labor, fair operating practices, consumers, business and development, and active community participation.

Based on the above, the following research hypotheses are proposed:

H1. Governance positively and significantly influences CSR, according to the perception of employees.

H2. Respect for human rights positively and significantly influences CSR, according to the perception of employees.

H3. Labor practices and significantly positive influence CSR, according to the perception of employees. 
H4. Respect for the environment influences positively and significantly CSR, according to the perception of employees.

H5. The implementation of fair operating practices positively and significantly influences CSR, according to the perception of employees.

H6. Respect for consumers positive and significant influence on CSR, according to the perception of employees.

H7. The active participation and community development positively and significantly influences CSR, according to the perception of employees.

\section{Method}

This research aims to identify the factors affecting CSR from the perception of human capital, based on the dictates of ISO 26000. The research is approached from a quantitative, transversal and explanatory perspective. The study was conducted in a public hospital in the region, in the city of Celaya, Guanajuato, Mexico.

The study subjects were 256 workers, who represent $90 \%$ of all workers and have an average age of 37 years, where $57 \%$ are female and $41 \%$ male. The individuals work in different areas such as management, storage, ambulances, clinical analysis, nursing, laundry, computer, maintenance, security, emergency services, among others. The gathering of information was carried out from January to April 2016.

Data were collected through a Likert scale questionnaire. Specifically, the governance dimension was measured by the Mitofsky Consultation instrument (2004). The dimensions of human rights, environment, labor practices, fair operating practices, consumer issues and active participation and community development were taken from the questionnaire by Cruz, Rositas \& Garcia (2013) (see Table 6).

Table 6. Operationalization of variables

\begin{tabular}{|c|c|c|}
\hline Variable & Dimensions & Definition \\
\hline Governance (GOV) & $\begin{array}{l}\text { Transparency } \\
\text { Respect internal and external } \\
\text { stakeholders. }\end{array}$ & $\begin{array}{l}\text { Decision-making system that the company } \\
\text { implements to ensure the achievement of } \\
\text { objectives. }\end{array}$ \\
\hline Human Rights (HR) & $\begin{array}{l}\text { Discrimination } \\
\text { Equal opportunities } \\
\text { Forced labor }\end{array}$ & $\begin{array}{l}\text { Respect for human rights and recognition } \\
\text { of their importance and universality. }\end{array}$ \\
\hline Labor Practices (LP) & $\begin{array}{l}\text { Safe working conditions } \\
\text { Quality in the work environment }\end{array}$ & $\begin{array}{l}\text { It includes the policies and practices } \\
\text { related to work carried out by an employee } \\
\text { in an organization. }\end{array}$ \\
\hline Environment (ENV) & $\begin{array}{l}\text { Environmental conservation } \\
\text { Decreased resource consumption }\end{array}$ & $\begin{array}{l}\text { Respect for and promotion of } \\
\text { environmental care in business } \\
\text { management. }\end{array}$ \\
\hline $\begin{array}{l}\text { Fair Operating Practices } \\
\text { (FOP) }\end{array}$ & $\begin{array}{l}\text { Code of ethics } \\
\text { Sanctioning corrupt practices } \\
\text { Communication CSR actions }\end{array}$ & $\begin{array}{l}\text { Ethical conduct that applies to a company } \\
\text { in all transactions carried out with its } \\
\text { stakeholders. }\end{array}$ \\
\hline Consumer issues $(\mathrm{CI})$ & $\begin{array}{l}\text { Consideration of Customers' opinions } \\
\text { Improving products and responsible } \\
\text { marketing }\end{array}$ & $\begin{array}{l}\text { Responsibility of the company with its } \\
\text { customers to meet their needs without risk } \\
\text { to them, providing accurate information on } \\
\text { the products and services offered. }\end{array}$ \\
\hline $\begin{array}{l}\text { Active participation and } \\
\text { community development } \\
\text { (PCD) }\end{array}$ & $\begin{array}{l}\text { Participation in Community programs } \\
\text { Support community infrastructure }\end{array}$ & $\begin{array}{l}\text { Company commitment to maintaining a } \\
\text { relationship of respect and community } \\
\text { support. }\end{array}$ \\
\hline $\begin{array}{l}\text { Level of Corporate } \\
\text { Social } \\
\text { (CSR) }\end{array}$ & $\begin{array}{l}\text { Performance of the company in relation } \\
\text { to its social responsibility }\end{array}$ & $\begin{array}{l}\text { Degree to which the company implements } \\
\text { a responsible with the various stakeholders } \\
\text { in the economic, social and environmental } \\
\text { philosophy. }\end{array}$ \\
\hline
\end{tabular}

Source: Prepared based on Cruz, Rositas and Garcia (2013), ISO 26000 (2010) and Mitofky (2004). 
Cronbach's alpha was calculated to evaluate the reliability of internal consistency of the instrument, obtaining 0.918 in total. Table 7 shows the coefficient for each dimension.

Table 7. Cronbach's alpha coefficients by dimension

\begin{tabular}{lr}
\hline Dimensions & Cronbach \\
\hline Governance & 0.919 \\
Human rights & 0.800 \\
Labor practices & 0.738 \\
Environment & 0.852 \\
Fair operating practices & 0.890 \\
Subject consumers & 0.866 \\
Active participation and community development & 0.870
\end{tabular}

Source: own data.

\section{Results}

For analysis of the results, it is important to note that the interpretation is the perception of the employee. The descriptive analysis of data is shown in Table 8. Human rights and governance of the company are the most important factors to the organization. This implies that there is transparency in decision-making, that the interests of stakeholders are respected, and that the company offers equal opportunities to its workers, and there is no discrimination.

On the other hand, labor practices and the participation of the business community are aspects of minor importance, since it has the lowest averages. According to the standard deviation, there is a greater dispersion in the perception of employees regarding work practices, and regarding the level of corporate social responsibility, as they showed the highest rates.

Table 8. Descriptive statistics of the variables

\begin{tabular}{lccccc}
\hline \multicolumn{1}{l}{ Variables } & $\mathrm{n}$ & $\begin{array}{c}\text { Minimum } \\
\text { value }\end{array}$ & $\begin{array}{c}\text { Maximum } \\
\text { value }\end{array}$ & Media & Std. Typ. \\
\hline Governance & 256 & 1.11 & 5.00 & 3.5902 & 0.85905 \\
Human rights & 256 & 1.00 & 5.00 & 3.8044 & 0.88117 \\
Labor practices & 256 & 1.00 & 5.00 & 2.9961 & 1.15639 \\
Environment & 256 & 1.00 & 5.00 & 3.4129 & 0.93274 \\
Fair Operating Practices & 256 & 1.00 & 5.00 & 3.0753 & 0.99620 \\
Consumer issues & 256 & 1.00 & 5.00 & 3.4922 & 0.99086 \\
$\begin{array}{l}\text { Active participation and community } \\
\text { development }\end{array}$ & 256 & 1.00 & 5.00 & 3.0195 & 0.95770 \\
Corporate social responsibility & 256 & 1.00 & 5.00 & 3.1641 & 1.10810 \\
\hline
\end{tabular}

Source: Own elaboration.

In the correlation analysis (see Table 9) it should be noted that all indices are positive and significant. Labor and environmental practices have the highest correlation index (.797), followed by the variables fair operating practices 
and the environment (.798), and finally governance and human rights (.704). Corporate social responsibility has positive and significant mean relationships with all variables. The strongest relationship is with CSR variables active participation and community development, governance and consumer opinion. This means that respect for consumers through adequate attention to customers and providing real information products and services is considered responsible behavior. Likewise, when the company takes into account the needs of the community it is expressing a commitment to society, and this is highly valued especially in a healthcare company. The variable that is least related to CSR is to human rights, compared with other variables.

Table 9. Correlation matrix

\begin{tabular}{lllllllll}
\hline & GOV & HR & LP & ENV & FOP & CI & PCD & CSR \\
\hline GOV & 1 & & & & & & & \\
HR & $.704^{* *}$ & 1 & & & & & & \\
LP & $.618^{*}$ & $.546^{* *}$ & 1 & & & & & \\
ENV & $.659^{* *}$ & $.648^{* *}$ & $.797^{* *}$ & 1 & & & & \\
FOP & $.608^{* *}$ & $.530^{* *}$ & $.652^{* *}$ & $.708^{* *}$ & 1 & & & \\
CI & $.644^{* *}$ & $.589^{* *}$ & $.616^{* *}$ & $.701^{* *}$ & $.662^{* *}$ & 1 & & \\
PCD & $.618^{* *}$ & $.497^{* *}$ & $.597^{* *}$ & $.659^{* *}$ & $.678^{* *}$ & $.696^{* *}$ & 1 & \\
CSR & $.599^{* *}$ & $.474^{* *}$ & $.536^{* *}$ & $.586^{* *}$ & $.579^{* *}$ & $.599^{* *}$ & $.615^{* *}$ & 1 \\
\hline
\end{tabular}

** The correlation is significant at $1 \%$. ${ }^{*}$ The correlation is significant at $5 \%$. Source: Prepared based on results of SPSS.

Regression analysis is presented in Table 10, where the coefficients of the variables are specified, the F-statistic and R2. The results show that $94.5 \%$ of the variation in the level of CSR is explained by the proposed variables. Governance, consumer issues and participation and community development have positive and significant coefficients. Human rights, labor practices, the environment and fair operating practices are not significant in the model.

Table 10. Multiple Regression Analysis

\begin{tabular}{lc}
\cline { 2 - 2 } Variables & Coefficients \\
\cline { 2 - 3 } Governance & $.301^{* *}$ \\
Human Rights (HR) & -.033 \\
Labor Practices (LP) & .036 \\
Environment (ENV) & .102 \\
Fair Operating Practices (FOP) & .128 \\
Consumer Affairs (ASC) & $.168^{*}$ \\
Participation and Community Development & $.257^{* *}$ \\
$\mathrm{~F}$ & 606.579 \\
$\mathrm{R}^{2}$ & .945 \\
\hline ** 1\% significance; * Significant at 5\%. Source: Prepared based on results of SPSS.
\end{tabular}

This implies that, based on the perception of employees, governance is a variable that influences the level of CSR. That is, when the company generates an atmosphere of trust to provide information on the organization to its various stakeholders freely, we talk about responsible behavior because there is transparency in its decision-making system. As Castelo and Lima mentioned (2008, cited in Testera Fuentes 2013), 'the companies conduct CSR activities and report them to their stakeholders to meet the standards and expectations they have and to visualize the assumption of 
such commitments' (own translation). Arrieta \& De la Cruz (2005) also highlights the importance of ethical and transparent practices in the management of hospitals. Thus, hypothesis one is accepted.

Regarding human rights, apparently, employees do not consider it a variable that influences the responsible behavior of the organization, and is, therefore, insignificant, so hypothesis 2 is not accepted. According to López, Ojeda and Ríos (2016), employees do not consider respect for human rights as a hallmark of socially responsible companies, but as a conduct expected of all companies. In this sense, companies must offer a deal of dignity to employees, provide equal opportunities, grant the right to unionize, the right to equal work, the right to social security, and freedom from discrimination.

In the regression model, labor practices were also insignificant and did not explain the responsible behavior of the company, based on the opinion of employees, so hypothesis 3 is not accepted. When a company creates a quality environment where teamwork is valued, appropriate communication channels exist alongside healthy working relationships, and trust is established physical and human conditions the company demonstrates responsible behavior. However, in this case, workers did not consider it relevant to determine the social responsibility of the company, even though it was expected to be of great importance for the worker. The above may be due to a deficiency in the safety of working conditions and flaws in the quality of the work environment of the company, but we consider the organization provides a very important service to society, which meets the healthcare needs of the community.

The results also show that the activities of the company in relation to the care of the environment are not significant to determine the level of CSR of the organization, based on the perception of the employees. Hypothesis 4 is, therefore, not accepted. These results are different from those expected as the conservation of the environment is one of the main axes of CSR as it is focused on implementing policies to reduce consumption of resources, to develop a culture of recycling, incorporating nonpolluting inputs and generating an environmental education throughout the company. However, for the employee, there are other dimensions of utmost importance that help explain the behavior responsible for the company, such as consumer behavior and society in general.

Fair operating practices relating to the code of ethics that governs the actions of the company in transactions with its stakeholders and the implementation of sanctions against corrupt practices is considered a variable that demonstrates the responsible behavior of companies according to the ISO 26000. However, in analyzing the perception of employees, these practices do not help explain the level of CSR in the organization studied, and are not significant in the model. Therefore, hypothesis 5 is not accepted. One would expect that in a health institution, codes of ethics be of great importance especially because it is a way to ensure the relevance of the service given and the vulnerability of the client.

Regarding hypothesis 6 , the results show that consumer affairs are a variable that helps determine the level of CSR, so this hypothesis is accepted. When an organization shows interest in meeting the needs of customers and serving those needs through goods and services without risk to the consumer, through responsible marketing, the company shows that it is socially responsible. In this regard, respect for consumers generates very clear benefits for the company, develop a positive reputation, customer loyalty, and better positioning. Also, these results are equal to those obtained by Lopez et al. (2016) who found that respect for consumers positively influences the company responsible behavior from the perspective of human capital.

Finally, the results show that the active participation and community development influences, according to the perception of employees, positively and significantly in CSR, so hypothesis 7 is accepted. When businesses get involved in the community through participation in community programs to address issues, make decisions and actions to improve the reality of society, it implies that the company has adopted the philosophy of CSR in their daily activities and strategies of the organization.

\section{Conclusions}

The aim of this paper is to analyze the factors that influence the responsible behavior of an organization in the health sector, depending on the perception of 256 workers. To analyze CSR, we formed a model based on ISO2600. The results show that governance, respect for consumer affairs, and active participation and community development positively and significantly influence the perception by employees of the level of social responsibility of the organization. This implies that, from the perspective of employees, the level of CSR is defined for the capacity of the hospitals to act in a transparent manner with stakeholders and for having clear rules in hospital administration. In these rules, it should be consider the development of values and ethical behaviors, because this implies that actions are oriented to common good. In this sense, ethic should be present in the behavior toward customers and employees, first of all, but also with the society. 
The emphasis on consumers and gobernability that show the results, are consistent with those found by Ramos (2013) who found that health institutions perform actions on behalf of consumers, have monitoring bodies, and have control over decision-making. Regarding the level of CSR, an average of 3.1 was obtained within a range of 1 to 5 , the same average obtained by Keyvanara, M., \& Saddat, H. (2015) in their study of 946 hospital staff. However, Perez \& Morales (2011) determined that CSR is nonexistent in hospitals.

These findings have several implications. Apparently, the treatment received by the client is of great importance for assessing responsible behavior, especially because it is a service company that involves people's health, and therefore the quality of service is of great importance. This means that organizations must ensure the needs of customers without risk to them, which will be difficult to achieve if not ensured by a code of ethics. While the results have shown the importance of the participation of the company in the development of the community, for the employees interviewed, being a public institution automatically grants the distinction of being a company that deals with society, but this does not mean that it is involved in educational, cultural and sports activities, to name a few. Moreover, concern for the community should include care for the environment, an approach that is not prioritized, at least in this case. On the other hand, the company must establish programs that improve the conditions and the working environment, as this is reflected in the attention received by the final consumer.

The academic community must also focus on the need to deepen the analysis of CSR in the health sector, for knowledge in the area is still scarce, especially in Mexico. Regarding the government sector, programs that promote CSR in the health sector must be urgently developed, especially for the important role it plays in society as a provider of health services in society, and even more, to establish mandatory standards aimed at companies to improve each of the dimensions of CSR.

This research has several limitations. The first limitation is that it is a case study, so we cannot generalize the results. The second limitation is that the assessment of CSR is evaluated only from the perception of employees, leaving out the points of view of other stakeholders. Future research should evaluate CSR in both public and private hospitals, using ISO26000.

\section{Acknowledgements}

Grateful to the Direction Supporting research and Master Degree (DAIP) of the University of Guanajuato for the translation and revision of this document.

\section{References}

Abreu, R., David, F., Crowther, D., Date, S., \& Exports, M. (2005). Corporate social responsibility is urgently needed in health care. Social Responsibility Journal, 1, 225-240. http://dx.doi.org/10.1108/eb045813

Ahlstedt, L., \& Jahn Kainen, I. (1971). Yritysorganisaatio yhteistoiminnan ohjausjaerjestelmaenae. Helsinki: Weilin + Goeoes.

Alkhafaji, A. (1989). A stakeholder approach to corporate governance. Managing in a dynamic environment. Westport, CT: Quorum Books.

Andriof, J., Waddock, S., Husted, B., \& Rahman, S. (2002). Unfolding Stakeholder Thinking: Theory, Responsibility and Engagement. Greenleaf Publishing, Sheffield, 1-18.

Androif, J., \& Waddock, S. (2002). Unfolding stakeholder engagement. En Andriof, J., Waddock, S., Husted, B. and Rahman, S.S. (Eds.), Unfolding Stakeholder Thinking: Theory, Responsibility and Engagement (pp. 19-42). Sheffield: Greenleaf.

Ansoff, I. (1965). Corporate Planning. New York: McGraw Hill.

Aristóteles (350 a.C.). Ética a Nicómaco. Retrieved from http://www.alcoberro.info/pdf/nicomaco.pdf

Arrieta, B., \& De la Cruz, C. (2005). La dimensión ética de la responsabilidad social. Bilbao: Universidad de Deusto.

Barnard, C. (1938). The functions of the executive. Cambridge, MA: Harvard University Press.

Beekun, R., \& Badawi, J. (2005). Balancing ethical responsibility among multiple organizational stakeholders: the Islamic perspective. Journal of Business Ethics, 60(2), 131-145. http://dx.doi.org/10.1007/s10551-004-8204-5

Berman, S., Wicks, A., Kotha, S., \& Jones, T. (1999). Does Stakeholder Orientation Matter? The Relationship Between Stakeholder Management Models and Firm Financial Performance. Academy of Management Review, 42(5), 488-506. http://dx.doi.org/10.1007/s10551-004-8204-5 
Bowen, H. (1953). Social Responsibility of the businessman. Harper \& Row, New York.

Bowie, N. (1988). The moral obligations of multinational corporations. Luper.

Brenner, S. (1993). The stakeholder theory of the firm and organizational decision making: Some propositions and a model, In J. Pasquero \& D. Collins (Eds.), Proceedings of the Fourth Annual Meeting of the International Association for Business and Society (pp. 205-210). San Diego.

Brenner, S. (1995). Stakeholder theory of the firm: Its consistency with current management techniques. En Ndsi, J. (Ed.), Understanding stakeholder thinking (pp. 75-96). Helsinki: LSR-Julkaisut Oy.

Brenner, S., \& Cochran, P. (1991). A stakeholder theory of the firm: Implications for business and society theory and research. Proceedings of the International Society for Business and Society, 449-467.

Carroll, A. (1993). Business and society: Ethics and stakeholder management (2nd ed.). Cincinnati: Southwestern.

Cersósimo, A. (2002). Notas preliminaries para el estudio de los conceptos de ética y moral en el Antiguo Egipto. Transoxiana. Journal de Estudios Orientales. Retrieved from http://www.transoxiana.org/0105/etica.html

Cicerón, M. (51 $\quad$ a.C.). Epistulae ad familiares. Retrieved from http://www.dominiopublico.gov.br/download/texto/ph000159.pdf

Clark, J. (1916). The changing basis of economic responsibility. Journal of political economy, 24, 209-229. http://dx.doi.org/10.1086/252799

Clarkson, A. (1994). A risk based model of stakeholder theory, Proceedings of the Second Toronto Conference on Stakeholder Theory. Toronto: Centre for Corporate Social Performance \& Ethics, University of Toronto.

Clarkson, M. (1995). The Toronto conference: reflections on stakeholder theory, Business \& Society, 33(1), 82-131.

Comte, A. (1851). Positive Polity. Retrieved from http://www.mindserpent.com/American_History/books/Comte/1875_comte_system_of_positive_polity_vol_01. pdf

Cornell, B., \& Shapiro, A. (1987). Corporate stakeholders and corporate finance. Financial Management, 16, 5-14. http://dx.doi.org/10.2307/3665543

Crosby, B., \& Bryson, J. (2005). Leadership for the Common Good. San Francisco, CA: Jossey-Bass.

Cruz, J., Rositas, J., \& García, J. (2013). Responsabilidad social empresarial: Investigación empírica-exploratoria sobre los conceptos de RSE y RSU. XVIII Congreso Internacional de Contaduría, Administración e Informática. México, D.F., UNAM.

Cutlip, S., Center, A., \& Broom, G.M. (2001). Relaciones públicas eficaces (Trad. E. Smyrli). Barcelona: Gestión 2000.

Dahlsrud, A. (2008). How Corporate Social Responsibility is Defined: an Analysis of 37 Definitions. Corporate Social Responsibility and Environmental Management, 15, 1-13. http://dx.doi.org/10.1002/csr.132

Dawkins, R. (1976). The selfish gene. Oxford: Oxfor University Press.

De la Garza, M., \& Guzmán, E. (2013). Estrategia organizacional en la responsabilidad social corporativa: una opción competitiva para las organizaciones. En Leal, F. y Ojeda, J. (Coord). Desarrollo de la responsabilidad social en las organizaciones (pp. 65-80). Universidad Autonoma de Aguascalientes, Aguascalientes, México.

Deneulin, S. (2006). Individual Well-being, Migration Remittances and the Common Good. The European Journal of Development Research, 18(1), 45-58. http://dx.doi.org/10.1080/09578810600572353

Dill, W. (1975). Public Participation in Corporate Planning. Long Range Planning, 8, 57-63.

Donaldson, T., \& Dunfee, W. (1994). Toward a unified conception of business ethics: integrative social contract theory. Academy of Management Review, 19(2), 252-284. http://dx.doi.org/10.2307/258705

Donaldson, T., \& Preston, L. (1995). The stakeholder theory of the corporation: concepts, evidence, and implications. Academy of Management Review, 20(1), 65-91. http://dx.doi.org/10.5465/AMR.1995.9503271992

Elkington, J. (1998). Cannibals with Forks: The Triple Bottom Line of 21st Century Business. New Society Publishers: Gabriola Island, Canada.

Epstein, E. (1987). The corporate social policy process: beyond business ethics, Corporate Responsibility, and Corporate Social Responsiveness. California Management Review, 29(3), 99-114. http://dx.doi.org/10.2307/41165254 
Evan, W., \& Freeman, R. (1988). A stakeholder theory of the modern corporation: Kantian capitalism, En Beauchamp, T. y Bowie, N. (Eds.), Ethical theory and business (pp. 75-84). Englewood Cliffs, NJ: Prentice-Hall.

Evans, R., \& Stoddart, G. (1990). Producing health, consuming health care. Social Science and Medicine, 31(12), 1347-63. http://dx.doi.org/10.1016/0277-9536(90)90074-3

Foy, S. (Ed.) Problems of international justice. Boulder, CO: Westview Press.

Frederick, W. (1987). Theories of Corporate Social Performance. En Sethi, S. y Flabe, C. (Ed.), Business and Society: Dimensions of Conflict and Cooperation (pp. 142-161). Lexington Books, New York.

Freeman, R. (1984). Strategic management: a stakeholder perspective. Pitman Publishing Inc, Boston.

Freeman, R. (1994). The politics of stakeholder theory: Some future directions. Business Ethics Quarterly, 4, 409-421. http://dx.doi.org/10.2307/3857340

Freeman, R. (2002). Stakeholder Theory of the Modern Corporation. En Donaldson, T. y Werhane, P. (Eds.), Ethical Issues in Business: A Philosophical Approach (pp. 38-48, 7th ed.). Prentice Hall, Englewood Cliffs, NJ.

Freeman, R., \& Evan, W. (1990). Corporate governance: A stakeholder interpretation. Journal of Behavioural Economics, 19, 337-359.

Freeman, R., \& Gilbert, D. (1987). Managing stakeholder relationships. En Sethi. S y Falbe, C. (Eds.), Business and society: Dimensions of conflict and cooperation (pp. 397-423). Lexington, MA: Lexington Books.

Freeman, R., \& Phillips, R. (2002, July). Stakeholder theory: A libertarian Defence. Business Ethics Quarterly, 12, 331-349.

Freeman, R., \& Reed, D. (1983). Stockholders and stakeholders: A new perspective on corporate governance. California Management Review, 25(3), 93-94. http://dx.doi.org/10.2307/41165018

Freeman, R., Harrison, J., Wicks, A., Parmar, B., \& De Colle, S. (2010). Stakeholder theory: the state of the art. Cambridge University Press.

García, D. (2005). La apuesta ética en las organizaciones sanitarias. Publicacions de la Universitat Jaume I. Servei de Comunicació i Publicacions. España.

González, E. (2004). Los restos éticos de la medicina gestionada. En García, D. (Ed.), Ética empresarial. Del diálogo a la confianza en la empresa (pp. 63-91). Madrid: Trotta.

Granillo, L., \& Ojeda, J. (2012). Gestión sustentable e inclusión social, stakeholders en ISO 26000, guía para la responsabilidad social en las organizaciones. Academic Journal, 4(3), 1215-1220.

Greasley, A. (1999). Operations Management in Business. Stanley Thornes (publishers) Ltd, UK.

Hall, R. (2000). An introduction to healthcare organizational ethics. Oxford: Oxford University Press.

Hammurabi. (1728 a.C.). El Código. Retrieved from http://www.edictum.com.ar/miWeb4/corpus.htm

Harwood, I. (2008). Embedding corporate responsibility into supply: A snapshot of progress. European Management Journal, 26(3), 166 - 174. http://dx.doi.org/10.1016/j.emj.2008.01.005

Hernández, V., \& Hernández, M. (2014). La integración de iniciativas socialmente responsables en la gestión de proveedores. En De la Rosa, M. (Coord.). Retos y oportunidades del desarrollo sustentable y la responsabilidad social (pp. 273-309). México, Universidad de Sonora.

Hill, C., \& Jones, T. (1992). Stakeholder-agency theory. Journal of Management Studies, 29(2), 131-154. http://dx.doi.org/10.1111/j.1467-6486.1992.tb00657.x

Hobbes, $\quad$ T. (1651). $\quad$ Leviathan. $\quad$ Retrieved from http://socserv2.socsci.mcmaster.ca/econ/ugcm/3113/hobbes/Leviathan.pdf

ISO26000 (2010), Guía de responsabilidad social. Retrieved from http://www.iso.org/iso/iso_26000_project_overview-es.pdf

Jaulín, C. (2013). La responsabilidad social en las organizaciones como capital social para gestionar el equilibrio armónico. Costes, derechos y beneficios. En Desarrollo de la Responsabilidad socil en las organizaciones, Leal, F. y Ojeda, J. (Coord). Editorial Universidad Autónoma de Aguascalientes. 
Jensen, J. (2009). Religion as the Unintended Product of Brain Functions in the 'Standard Cognitive Science of Religion Model'. En Stausberg, M. (Ed)., Contemporary Theories of Religion: A Critical Companion (pp. 129-155). New York: Routledge

Jensen, M. (2002). Value maximization, stakeholder theory, and the corporate objective function. Business Ethics Quarterly, 12(3), 235-256. http://dx.doi.org/10.2307/3857812

Johnson-Cramer, M., Berman, S., \& Post, J. (2003). Re-examining the concept of stakeholder management, En Andriof, J., Waddock, S., Husted, B. and Rahman, S.S. (Eds.), Unfolding Stakeholder Thinking: Relationships, Communication, Reporting and Performance (pp. 145-161). Sheffield: Greenleaf.

Jones, T. (1980). Corporate Social Responsibility revisited, redefined. California Management Review, 22(2), 59-67. http://dx.doi.org/10.2307/41164877

Jones, T. (1995). Instrumental stakeholder theory: a synthesis of ethics and economics. Academy of Management Review, 20(2), 404-437. http://dx.doi.org/10.5465/AMR.1995.9507312924

Jones, T., \& Wicks, A. (1999). Convergent stakeholder theory. The Academy of Management Review, 24(2), 206-221. http://dx.doi.org/10.5465/AMR.1999.1893929

Kaler, J. (2002). Morality and strategy in stakeholder identification. Journal of Business Ethics, 39(1/2), 91-99.

Keyvanara, M., \& Saadat, H. (2015). Social responsibility of the hospitals in Isfahan City, Iran: Results from cross sectorial survey. International Journal of Healt Policy and Management, 4(8), 517-522. http://dx.doi.org/10.15171/ijhpm.2015.29

Kreps, T. (1940). Measurement of the social performance of business. US Printing Office, Washington, USA.

Langtry, B. (1994). Stakeholders and the moral responsibilities of business. Business Ethics Quarterly, 4, 431-443. http://dx.doi.org/10.2307/3857342

Locke, J. (1689). Cartas sobre la tolerancia. Retrieved from http://www.hacer.org/pdf/Locke01.pdf

López, A., Contreras, R., \& Molina, R. (2011), La Responsabilidad Social Empresarial como Estrategia de Competitividad en el Sector Alimentario. Revista Cuadernos de Administración, 24(43), 261-283.

López, A., Ojeda, J., \& Ríos, M. (2106). La responsabilidad social empresarial desde la perspectiva del capital humano. Estudio de un caso. Revista de Contabilidad - Spanish Accounting Review. http://dx.doi.org/10.1016/j.rcsar.2016.01.001

Marín, F. (2008). Responsabilidad social corporativa y comunicación. Editorial Fragua.

Medina, P. (2012). La responsabilidad social corporativa en hospitales: un nuevo desafío para la comunicación institucional. Revista Española de Comunicación en Salud, 13(1), 77-87.

Mills, J. (1863). $\quad$ El $\quad$ utilitarismo. $\quad$ Retrieved from http://213.0.8.18/portal/Educantabria/ContenidosEducativosDigitales/Bachillerato/CITEXFI/citex/CIT/Mill/mill texto.pdf

Mitchell, R., Agle, B., \& Wood, D. (1997). Toward a theory of stakeholder identification and salience: defining the principle of who and what really counts. The Academy of Management Review, 22(4), 853-886. http://dx.doi.org/10.5465/AMR.1997.9711022105

Mitofsky. (2004). La imagen de marca, un fenómeno social. Madrid: Paidós.

Mitroff, I., Emshoff, J., \& Kilmann, R. (1979). Assumptional analysis: A methodology for strategic problem solving. Management Science, 25, 583-593. http://dx.doi.org/10.1287/mnsc.25.6.583

Morales, J., Galeano, C., \& Muñoz, J. (2014). Perfil de responsabilidad social empresarial para entidades promotoras de salud - régimen contributivo de Bucaramanga y su área metropolitana. Revista Cuidarte, 5(1), 633 - 643.

Moser, M. (1986). A Framework for Analyzing Corporate Social Responsibility. Journal of Business Ethics, 5(1), 69-72. http://dx.doi.org/10.1007/BF02116146

Murphy, M. (2005). The common good. The review of metaphysics, 59(1), 133-164.

Näsi, J. (1995). What is stakeholder thinking? A snapshot of a social theory of the firm. En Ndsi, J. (Ed.), Understanding stakeholder thinking (pp. 19-32). Helsinki: LSR-Julkaisut Oy.

Ojeda, J., \& Lira, G. (2014). Responsabilidad social. En Conraud, E. (Coord). Responsabilidad social en empresas multinacionales en el Estado de Guanajuato (pp. 31-52), Guanajuato, México. Ed. Pearson. 
Ortiz, M., \& Palavecino, S. (2005). Bioética para una salud pública con responsabilidad social. Acta Bioethica, 11(1), 65-76.

Ozar, B. Wherane, P., \& Emanuel, L. (2000). Organizational ethics in health care: toward a model for ethical decision making by provider organizations. Chicago: Institute for Ethics, AMA.

Panwar, R., Han, X., \& Hansen, E. (2010). A demographic examination of societal views regarding corporate social responsibility in the US forest products industry. Forest Policy and Economics, 12, 121-128. http://dx.doi.org/10.1016/j.forpol.2009.09.003

Pérez, M., \& Morales, J. (2011). Revisión de los orígenes de la responsabilidad social empresarial en el sector salud en Colombia. Revista CUIDARTE, 2(1), 1-15. http://dx.doi.org/10.15649/cuidarte.v2i1.59

Phillips, R. (1997). Stakeholder Theory and a Principle of Fairness. Business Ethics Quarterly, 7, 51-67. http://dx.doi.org/10.2307/3857232

Phillips, R. (2003). Stakeholder theory and organizational ethics. San Francisco, CA: Berrettkoehler.

Platón. (387 a.C.). La república. Madrid: Centro de Estudios Políticos y Constitucionales.

Post, J., Preston, L., \& Sachs, S. (2002). Redefining the Corporation, Stakeholder Management and Organizational Wealth. Stanford, CT: Stanford University Press.

Ramos, K. (2013). La responsabilidad social empresarial de las entidades del sector salud: descripción y análisis crítico de la RSE en los códigos de buen gobierno, ética y conducta de las principales entidades promotoras de salud colombianas. Tesis de Maestría. Universidad Nacional de Colombia, Facultad de Ciencias Económicas, Maestría en Administración, Bogotá, Colombia.

Sacconi, L. (2004). Corporate social responsibility (CSR) as a model of extended corporate governance: an explanation based on the economic theories of social contract, reputation and reciprocal conformism. LIUC. Ethics Law and Economics, 142. http://dx.doi.org/10.2139/ssrn.514522

San Agustín. (426). La ciudad de Dios. Retrieved from http://historicodigital.com/download/la-ciudad-de-dios.pdf

Savage, G., Nix, T., Whitehead, C., \& Blair, J. (1991). Strategies for assessing and managing organizational stakeholders. Academy of Management Executive, 5, 61-75. http://dx.doi.org/10.5465/AME.1991.4274682

Sheldon, O. (1924). The Philosophy of Management. Sir Isaac Pitman and Sons Ltd: London, England, 70-99.

Simón, C., \& Martínez, J. (2002). The impact of corporate social responsibility policies on the employees' psychological contract. Working Papers Economia, 02-33, 1-9.

Simon, H. (1945). Administrative behavior. New York: Free Press.

Smith, A. (1776). Investigación de la naturaleza y causas de la riqueza de las naciones. Retrieved from http://marxists.org/espanol/smith_adam/1776/riqueza/smith-tomo1.pdf

Spencer, E., Mills, A., Rorty, M., \& Werhane, P.H. (2000). Organization ethics in health care. Oxford: Oxford.

Testera Fuentes, A. (2013). Análisis de los factores determinantes de la transparencia en RSC en las empresas españolas cotizadas. Intagible Capital.

Thompson, J., Wartick, S., \& Smith, H. (1991). Integrating corporate social performance and stakeholder management: Implications for a research agenda in small business. Research in Corporate Social Performance and Policy, 12, 207-230. University Press.

Vesser, W., Matten, D., Pohl, M., Tolhurst, N., \& Böhmer, K. (2007). The A to Z of Corporate Social Responsibility: A Complete Reference Guide to Concepts, Codes and Organisations. ICCA Publications.

Wartick, S., \& Cochran, P. (1985). The evolution of the corporate social performance model. Academy of Management Review, 10(4), 758-769. http://dx.doi.org/10.5465/AMR.1985.4279099

Werther, W. B., \& Chandler, D. (2011). Strategic corporate social responsibility: Stakeholders in a global environment. London: Sage Publications.

Wicks, A., Gilbert, D., \& Freeman, R. (1994). A feminist reinterpretation of the stake-holder concept. Business Ethics Quarterly, 4(4), 475-497.
Zaratustra.
$(1767$
a.C.)
Los Gathas.
Retrieved
from http://gathagatha.files.wordpress.com/2013/08/gathas-los-cantos-divines-de-zaratustra-spanish-edition.pdf 